\title{
Epithelial Cell Line Derived from Endometriotic Lesion Mimics Macrophage Nervous Mechanism of Pain Generation on Proteome and Metabolome Levels
}

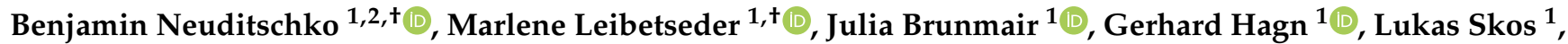 \\ Marlene C. Gerner ${ }^{3}\left(\mathbb{D}\right.$, Samuel M. Meier-Menches ${ }^{1,2,4}\left(\mathbb{D}\right.$, Iveta Yotova ${ }^{5}$ id and Christopher Gerner ${ }^{1,4, *(D)}$
}

1 Department of Analytical Chemistry, Faculty of Chemistry, University of Vienna, Waehringer Straße 38, 1090 Vienna, Austria; benjamin.neuditschko@univie.ac.at (B.N.); marlene_leibetseder@gmx.at (M.L.); julia.brunmair@univie.ac.at (J.B.); gerhard.hagn@univie.ac.at (G.H.); lukas.skos@univie.ac.at (L.S.); samuel.meier@univie.ac.at (S.M.M.-M.)

2 Department of Inorganic Chemistry, Faculty of Chemistry, University of Vienna, Waehringer Straße 42, 1090 Vienna, Austria

3 Division of Biomedical Science, University of Applied Sciences, FH Campus Wien, Favoritenstraße 226, 1100 Vienna, Austria; marlene.gerner@fh-campuswien.ac.at

4 Joint Metabolome Facility, Faculty of Chemistry, University of Vienna, Waehringer Straße 38, 1090 Vienna, Austria

check for updates

Citation: Neuditschko, B.; Leibetseder, M.; Brunmair, J.; Hagn, G.; Skos, L.; Gerner, M.C.; Meier-Menches, S.M.; Yotova, I.; Gerner, C. Epithelial Cell Line Derived from Endometriotic Lesion Mimics Macrophage Nervous Mechanism of Pain Generation on Proteome and Metabolome Levels. Biomolecules 2021, 11, 1230. https:// doi.org/10.3390/biom11081230

Academic Editors: Peter

Roman Jungblut and Vladimir N. Uversky

Received: 20 July 2021

Accepted: 13 August 2021

Published: 17 August 2021

Publisher's Note: MDPI stays neutral with regard to jurisdictional claims in published maps and institutional affiliations.

Copyright: (c) 2021 by the authors. Licensee MDPI, Basel, Switzerland. This article is an open access article distributed under the terms and conditions of the Creative Commons Attribution (CC BY) license (https:/ / creativecommons.org/licenses/by/ $4.0 /)$.
5 Department of Obstetrics and Gynaecology, Medical University of Vienna, Spitalgasse 23, 1090 Vienna, Austria; iveta.yotova@meduniwien.ac.at

* Correspondence: christopher.gerner@univie.ac.at

$\dagger$ Authors contributed equally.

Abstract: Endometriosis is a benign disease affecting one in ten women of reproductive age worldwide. Although the pain level is not correlated to the extent of the disease, it is still one of the cardinal symptoms strongly affecting the patients' quality of life. Yet, a molecular mechanism of this pathology, including the formation of pain, remains to be defined. Recent studies have indicated a close interaction between newly generated nerve cells and macrophages, leading to neurogenic inflammation in the pelvic area. In this context, the responsiveness of an endometriotic cell culture model was characterized upon inflammatory stimulation by employing a multi-omics approach, including proteomics, metabolomics and eicosanoid analysis. Differential proteomic profiling of the $12-Z$ endometriotic cell line treated with TNF $\alpha$ and IL1 $\beta$ unexpectedly showed that the inflammatory stimulation was able to induce a protein signature associated with neuroangiogenesis, specifically including neuropilins (NRP1/2). Untargeted metabolomic profiling in the same setup further revealed that the endometriotic cells were capable of the autonomous production of 7,8-dihydrobiopterin (BH2), 7,8-dihydroneopterin, normetanephrine and epinephrine. These metabolites are related to the development of neuropathic pain and the former three were found up-regulated upon inflammatory stimulation. Additionally, 12-Z cells were found to secrete the mono-oxygenated oxylipin 16-HETE, a known inhibitor of neutrophil aggregation and adhesion. Thus, inflammatory stimulation of endometriotic $12-Z$ cells led to specific protein and metabolite expression changes suggesting a direct involvement of these epithelial-like cells in endometriosis pain development.

Keywords: endometriosis; inflammation; metabolomics; multi-omics; proteomics

\section{Introduction}

Endometriosis is a chronic inflammatory disease describing the abnormal growth of uterine tissue outside of the uterine cavity in the pelvic area [1]. Endometriotic cells are characterized by invasive phenotypes. They successfully attach to pelvic organs and cause pelvic inflammation [2,3]. Studies estimate that the disease is affecting about 1 in 10 women worldwide. The clinical symptoms include dysmenorrhea, dyspareunia, chronic pelvic pain and infertility. To date, there exists no curative treatment [1]. As one of 
the cardinal symptoms, pain strongly affects the patients' quality of life and can only be treated symptomatically so far. A large fraction of the published studies focused on phenotypic investigations and the molecular mechanisms, especially those associated with pain development, remain to be fully elucidated [4].

According to the rAFS/ASRM system, the extent of the disease does not correlate with the pain level experienced by individual patients [5]. The severity of the pain sensation seems to be connected to a mixture of neuropathy, neurogenic inflammation, nociception and hyperalgesia [6]. It is known that the lesion's surrounding nerves are infiltrated and compressed by endometriotic cells [7]. Moreover, there is evidence that nascent nerve cells can be attracted by the endometriotic lesion. Their inflammatory activated state may also directly cause and transmit pain stimuli to the central nervous system [8]. Some nerve cells may even release proinflammatory factors, which ultimately lead to neurogenic inflammation and increased local vascular permeability, enhancing migration of ectopic endometrial cells [9-11]. Furthermore, it is well accepted that endometriosis-associated pain is directly linked to dorsal root ganglion neurons [12].

Immunological dysregulation seems to represent a main pathogenesis driver in endometriosis [13]. Normally, cell-mediated immune responses contribute to the elimination of immune invaders and clearance of ectopic endometrial tissue. In endometriosis, the clearance of endometrial tissue in the peritoneal cavity is abolished due to an impaired immune response at the site of implantation [14,15]. Deregulated T-cell immunity and a suppressed activity of macrophages and NK cells were found to contribute to this process [16]. The activation of an inflammatory response in the peritoneum of women with the disease leads to local production of cytokines, chemokines and growth factors that enhance the growth of the ectopic endometrial tissue by inhibiting normal apoptotic processes and promoting local angiogenesis and neurogenesis [17]. The macrophage-nervous axis in endometriosis is commonly accepted to be the main cause for disease-associated pain [18]. Indeed, nerve infiltration is positively correlated with high density of tissue-resident macrophages in the lesion [19]. Alternatively, these nerve fibres are attracted by the action of semaphorins. As semaphorins normally regulate axon migration, axonal growth and guidance, altered semaphorin secretion may lead to aberrant nervous innervation in endometriosis [18]. Infiltrating the endometriotic lesions, they secrete neuroangiogenic factors and create a neovasculative environment [20]. Herein, especially VEGF secretion plays an important role in axonal outgrowth functioning as a neurotrophic factor [21,22]. Once neuroangiogenesis and infiltration in nerve fibres was initiated by aberrant inflammatory signaling, the endometriotic lesion may be create its own altered microenvironment [23].

Macrophages secrete tumour necrosis factor $\alpha(\mathrm{TNF} \alpha)$ and interleukin-1 $\beta$ (IL1 $\beta)$ that contribute to disease progression $[24,25]$. These inflammatory cytokines can mediate neurogenic inflammation and secretion of further neuroangiogenic factors [26,27]. TNF $\alpha$ signaling increases the transient receptor potential vanilloid 1 (TRPV1) nociception in the dorsal root neurons which contributes to hyperalgesia and neuropathic pain sensation $[28,29]$. It was also found to sensitize sensory nerves to a constant induction of the action potential via TRPV1 in patients, mainly through overexpression of voltage-gated sodium channels [27]. TRPV1 expression is also increased in uterosacral ligaments in endometriosis patients [30] and it has been shown that pain is often driven by dorsal root ganglion neurons, in association with TRPV1 [12]. Neurogenesis seems to be at least partially responsible for neuropathic pain experiences [31,32]. Therefore, the molecular mechanisms of neurogenesis in endometriosis need to be comprehensively characterized to contribute towards novel therapy options in endometriosis pain management.

During the last years proteomics and metabolomics analysis were applied to uncover markers for early detection of endometriosis and to understand the molecular changes associated with its pathophysiology [33-35]. However, the use of these omics techniques is still sparse in endometriosis and multi-omics profiling was not yet applied, to the best of our knowledge. Combining proteomic with metabolomic profiling is especially attractive, since it may support a functional interpretation of the involved pathways. In addition, 
signaling lipids are key players during inflamation and act in a concerted fashion with proteins $[36,37]$. Thus, we have applied an in-depth proteome, metabolome and eicosanoid profiling of the endometriotic epithelial cell line $12-Z$ to investigate and characterize their responsiveness towards inflammatory signals. The cell line was isolated from a patient with peritoneal endometriosis and immortalized by Starzinski-Powitz [38]. 12-Z was characterized as epithelial-like (cytokeratin-positive/E-cadherin negative) and using a matrigel assay it was shown that the cell line was highly invasive [38]. To simulate the inflammatory macrophage signaling, the cells were treated with the cytokines TNF $\alpha$ or IL1 $\beta$, which are typically upregulated in endometriotic lesions of patients [39]. We provide proteomic and metabolic evidence that the endometriotic $12-Z$ cells may independently express key mediators of neuroangiogenesis and neuropathic pain.

\section{Material \& Methods}

\subsection{Cell Culture}

The $12-Z$ cell line was a generous gift of Dr. Anna Starzinski-Powitz (Goethe-Universität Frankfurt) [38]. Human epithelial endometriotic cell line 12-Z was cultivated in DMEMF12 phenolredfree (Gibco, Thermo Fisher Scientific, Vienna, Austria) with 10\% $(v / v)$ heat inactivated fetal calf serum (FCS, SigmaAldrich, Vienna, Austria) and $1 \%(v / v)$ penicillin and streptomycin (Sigma-Aldrich, Vienna, Austria). Cultivation was done in humidified incubators at $37^{\circ} \mathrm{C}$ and $5 \% \mathrm{CO}_{2}$. The $12-\mathrm{Z}$ cell line was grown in $\mathrm{T} 75$ polystyrene cell culture flasks with cell growth surface for adherent cells (Sarstedt, Wiener Neudorf, Austria). Cells were sub-cultured every 3-4 days at a 1:3 ratio. Cells were cultivated until they reached a concentration of $80 \%$ confluency. Cell counting was performed using a MOXI Z mini automated cell counter (ORFLO Technologies, Ketchum, ID, USA) using Moxi Z Type $\mathrm{M}$ cassettes (ORFLO Technologies, Ketchum, ID, USA). Cells were routinely checked for mycoplasma contamination using MycoAlert ${ }^{\mathrm{TM}}$ mycoplasma detection kit (Szabo-Scanidc, Vienna, Austria). Cells were seeded on a 6-well plate with cell growth surface for adherent cells (Sarstedt, Wiener Neudorf, Austria) at a density of 300.000 cells/well in $3 \mathrm{~mL}$ growth medium. Inflammatory stimulation was applied for $48 \mathrm{~h}$ at a concentration of $10 \mathrm{ng} \mathrm{mL}^{-1}$ with either TNF $\alpha$ or IL1 $\beta$ (both Sigma-Aldrich).

\subsection{Proteomics}

After the indicated treatment, the cells were washed twice with PBS and fractionation was performed as previously described [40]. Isotonic lysis buffer $(1 \mathrm{~mL}$ of $10 \mathrm{mM}$ HEPES/NaOH, pH 7.4, $0.25 \mathrm{M}$ sucrose, $10 \mathrm{mM} \mathrm{NaCl}, 3 \mathrm{mM} \mathrm{MgCl}_{2}, 0.5 \%$ Triton $\times 100$, protease and phosphatase inhibitor cocktail (Sigma-Aldrich)) was added to the cells, which were scraped using a cell scraper. Cell lysis was achieved using mechanical shear stress employing a syringe and a needle. After centrifugation at $2270 \times g$ for 5 min supernatant containing cytoplasmic proteins was precipitated in $4 \mathrm{~mL}$ of cold $\mathrm{EtOH}$ overnight.

Protein sample preparation: The ethanolic protein suspension was centrifuged at $4536 \mathrm{~g}$ for $30 \mathrm{~min}\left(4^{\circ} \mathrm{C}\right)$. The supernatant was discarded, while the protein pellet was dried and resuspended in lysis buffer ( $8 \mathrm{M}$ urea, $50 \mathrm{mM}$ TEAB, 5\% SDS). Protein concentration was determined using the bicinchoninic acid assay. An aliquot of the samples containing $20 \mu \mathrm{g}$ protein was digested using a modified Protifi protocol [41]. In short, the samples were diluted to a concentration of $1 \mu \mathrm{g} \mu \mathrm{L}^{-1}$. The diluted sample $(20 \mu \mathrm{g}$ in $20 \mu \mathrm{L})$ were pipetted into a $1.5 \mathrm{~mL}$ Eppendorf microcentrifuge tube and $20 \mu \mathrm{L}$ of DTT $(64 \mathrm{mM})$ was added. The samples were heated for $10 \mathrm{~min}$ at $95^{\circ} \mathrm{C}$ under constant shaking ( $300 \mathrm{rpm}$ ). The samples were cooled to room temperature, treated with iodacetamide $(5 \mu \mathrm{L}$ of $486 \mathrm{mM}$ solution, and incubated in the dark for $30 \mathrm{~min}$ at $30^{\circ} \mathrm{C}$ and $300 \mathrm{rpm}$. Afterwards, phosphoric acid ( $4.5 \mu \mathrm{L}$ of $12 \%$ ) was added, resulting in $1.2 \%$ final concentration of phosphoric acid. S-Trap buffer $(297 \mu \mathrm{L}, 90 \% \mathrm{MeOH}(v / v), 0.1 \mathrm{M} \mathrm{TEAB})$ was added to the solution. The sample was loaded on the Protifi S-Trap column and washed 4 times with S-trap buffer $(150 \mu \mathrm{L})$. Trypsin/LysC (MS grade; Promega Corporation, Madison, WI, USA) was added in a 1:40 
ratio $\left(0.5 \mu \mathrm{g}\right.$ for $20 \mu \mathrm{g}$ protein). After digestion for $2 \mathrm{~h}$ at $37^{\circ} \mathrm{C}$ peptides were eluted, dried using a SpeedVac and stored until further analysis.

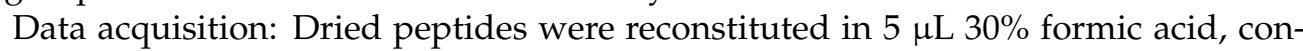
taining four synthetic peptides, for quality control [42]. The samples were further diluted with $40 \mu \mathrm{L}$ mobile phase $\mathrm{A}\left(97.9 \% \mathrm{H}_{2} \mathrm{O}, 2 \%\right.$ acetonitrile, $0.1 \%$ formic acid). Peptides were analyzed with a Dionex UltiMate 3000 Nano LC system coupled to a Q Exactive Orbitrap mass spectrometer (Thermo Fisher Scientific, Vienna, Austria) using a previously published method [40]. In short, peptides were separated on a $50 \mathrm{~cm} \times 75 \mu \mathrm{m}$ PepMap100 analytical column (Thermo Fisher Scientific), at a flow rate of $300 \mathrm{~nL} \mathrm{~min}{ }^{-1}$. Gradient elution of the peptides was achieved by increasing the mobile phase $\mathrm{B}\left(79.9 \%\right.$ acetonitrile, $20 \% \mathrm{H}_{2} \mathrm{O}, 0.1 \%$ formic acid) from $8 \%$ to $40 \%$, with a total chromatographic run time of 135 min including washing and equilibration. Mass spectrometric resolution on the MS1 level was set to 70,000 (at $m / z 200$ ) with a scan range from $m / z 400-1400$. The 12 most abundant peptide ions were selected for fragmentation (Top12) at 30\% normalized collision energy and analyzed in the Orbitrap at a resolution of 17,500 (at $\mathrm{m} / \mathrm{z} 200)$.

Data analysis: Data was analyzedanalyzed in settings as previously described [42]. Briefly, raw data was submitted to the freely available software MaxQuant (version 1.6.6.0) [43] utilizing the Andromeda search engine. A minimum of two peptide identifications, at least one of them being a unique peptide, was required for valid protein identification. The false discovery rate (FDR) was set to 0.01 on both peptide and protein level. Uniprot database (Human, version 03/2018, reviewed entries only, 20,316 protein entries) was used to generate the fasta file used for the search. For statistical data evaluation MaxQuant companion software Perseus (version 1.6.1.0) was used. Reverse sequences and potential contaminants as well as proteins identified only by site were removed. Label-free quantification (LFQ) values were converted to $\log 2(x)$ and technical replicates averaged. Proteins were filtered for valid values, keeping only proteins that were identified in at least three measurements of one sample group. Evaluation of regulatory events between different samples groups was achieved by two-sided t-tests using a FDR $<0.05$ calculated by permutation-based test $[44,45]$. Significantly regulated proteins were further analyzed using the Cytoscape [46] plugin ClueGo [47] with default settings. Gene ontology for Biological Processes (GOBP) was used as search space with medium network specificity. Statistical options were set to two-sided hypergeometriy test with Bonferroni step down p-value correction. String [48] analysis was further used to display protein network connections of regulated proteins. STRING protein query of species homo sapiens was used with a confidence (score) cut-off of 0.4 and with 0 additional interactors allowed. The mass spectrometry proteomics data have been deposited to the ProteomeXchange Consortium via the PRIDE [49] partner repository with the dataset identifier PXD022354 and 10.6019/PXD022354.

\subsection{Eicosanoid Analysis}

Eicosanoid sample collection and preparation: Supernatants from cell culture experiments or medium $(3 \mathrm{~mL})$ was added to cold ethanol $\left(12 \mathrm{~mL}, \mathrm{EtOH}\right.$, abs. $99 \%,-20{ }^{\circ} \mathrm{C}$; AustroAlco) containing an internal standard mixture of 12S-HETE-d8, 15S-Hete-d8, 5-OxoETE-d7, 11.12-DiHETrE-d11, PGE-d4 and 20-HETE-d6 (each 100 nM; Cayman Europe, Tallinn, Estonia). The samples were stored over-night at $-20{ }^{\circ} \mathrm{C}$. After centrifugation (30 min, $5000 \mathrm{rpm}, 4^{\circ} \mathrm{C}$ ), the supernatant was transferred to a new $15 \mathrm{~mL}$ Falcon ${ }^{\mathrm{TM}}$ tube and $\mathrm{EtOH}$ was evaporated via vacuum centrifugation $\left(37^{\circ} \mathrm{C}\right)$ until the original sample volume was accomplished. Samples were loaded on preconditioned StrataX solid phase extraction (SPE) columns (30 $\mathrm{mg} \mathrm{mL}^{-1}$; Phenomenex, Torrance, CA, USA) using Pasteur pipettes. SPE columns were washed with MS grade water $(3 \mathrm{~mL})$ and elution of eicosanoids was performed with ice-cold methanol $(500 \mu \mathrm{L}, \mathrm{MeOH}$ abs.; VWR International, Vienna, Austria) containing 2\% formic acid (FA; Sigma-Aldrich). MeOH was evaporated under a gentle stream of nitrogen at room temperature and the samples were reconstituted in $150 \mu \mathrm{L}$ reconstitution buffer $\left(\mathrm{H}_{2} \mathrm{O}: \mathrm{ACN}: \mathrm{MeOH}+0.2 \% \mathrm{FA}-\mathrm{vol} \%\right.$ 65:31.5:3.5), including 
a second mixture of internal standards, including 5S-HETE-d8, 14.15-DiHETrE-d11 and 8-iso-PGF2a-d4 (10-100 nM; Cayman Europe, Tallinn, Estonia). Reconstituted samples were stored at $+4^{\circ} \mathrm{C}$ and measured subsequently via LC-MS/MS.

Data acquisition: Separation of eicosanoids was performed on a Thermo Scientific ${ }^{\mathrm{TM}}$ Vanquish $^{\mathrm{TM}}$ (UHPLC) system equipped with a Kinete ${ }^{\circledR}$ C18-column $(2.6 \mu \mathrm{m}$ C18 $100 \AA$, LC Column $150 \times 2.1 \mathrm{~mm}$; Phenomene $\left.{ }^{\circledR}\right)$. All samples were analyzed in technical duplicates. The injection volume was $20 \mu \mathrm{L}$ and the flow rate was kept at $200 \mu \mathrm{L} \mathrm{min}{ }^{-1}$. The UHPLC method included a gradient flow profile (mobile phase $\mathrm{A}: \mathrm{H}_{2} \mathrm{O}+0.2 \% \mathrm{FA}$, mobile phase $\mathrm{B}$ : ACN:MeOH (vol\% 90:10) + 0.2\% FA) starting at 35\% B and increasing to $90 \% \mathrm{~B}(1-10 \mathrm{~min})$, further increasing to $99 \% \mathrm{~B}$ within $0.5 \mathrm{~min}$ and held for $5 \mathrm{~min}$. Afterwards solvent B was decreased to the initial level of $35 \%$ within $0.5 \mathrm{~min}$ and the column was equilibrated for $4 \mathrm{~min}$, resulting in a total run time of $20 \mathrm{~min}$. The column oven temperature was set to $40{ }^{\circ} \mathrm{C}$. The UHPLC system was coupled to a Q Exactive ${ }^{\mathrm{TM}}$ HF Quadrupole-Orbitrap ${ }^{\mathrm{TM}}$ mass spectrometer (Thermo Fisher Scientific, Austria), equipped with a HESI source for negative ionization to perform the mass spectrometric analysis. The resolution on the MS1 level was set to 60,000 (at $\mathrm{m} / \mathrm{z} 200$ ) with a scan range from $\mathrm{m} / \mathrm{z} 250-700$. The two most abundant precursor ions were picked for fragmentation (HCD 24 normalized collision energy), preferentially from an inclusion list containing $\mathrm{m} / z 31$ values specific for eicosanoids and their precursor molecules. Resulting fragments were analyzed on the MS2 level at a resolution of $15,000($ at $\mathrm{m} / \mathrm{z} 200)$. Operating in negative ionization mode, a spray voltage of $2.2 \mathrm{kV}$ and a capillary temperature of $253^{\circ} \mathrm{C}$ were applied. Sheath gas was set to 46 and the auxiliary gas to 10 (arbitrary units).

Data analysis: Data interpretation of raw files generated by the $\mathrm{Q}$ Exactive ${ }^{\mathrm{TM}} \mathrm{HF}$ Quadrupole-Orbitrap ${ }^{\mathrm{TM}}$ mass spectrometer was performed manually using Thermo Xcalibur $^{\mathrm{TM}}$ 4.1.31.9 (Qual browser). Spectra were compared with reference spectra from the Lipid Maps depository library from July 2018 [50]. Peaks were integrated using the TraceFinder ${ }^{\mathrm{TM}}$ software package (version 4.1-Thermo Scientific, Vienna, Austria).

\subsection{Metabolomics}

Metabolomic sample collection and preparation: For metabolomics analysis, cells were seeded at $10^{6}$ cells per T25 flask in complete medium $(5 \mathrm{~mL})$ and left to adhere over-night. They were then treated with IL1 $\beta$ or TNF $\alpha$ for $48 \mathrm{~h}$ similarly to the proteomic experiment. Thereafter, the medium was removed and centrifuged (1100 rpm, $\left.2 \mathrm{~min}, 4^{\circ} \mathrm{C}\right)$. An aliquot $(200 \mu \mathrm{L})$ of each medium sample was precipitated in cold $\mathrm{MeOH}(100 \%, 800 \mu \mathrm{L})$ and stored at $-80{ }^{\circ} \mathrm{C}$. The methanolic solution contained dopamine- $\mathrm{d} 4$, melatonin- $\mathrm{d} 4$ (both Santa Cruz Biotechnology, Dallas, TX, USA) and N-acetyl-serotonin-d3 (Toronto Research Chemicals BIOZOL) as internal standards at concentrations of $120 \mathrm{pg} \mu \mathrm{L}^{-1}$. The cell samples were washed once with PBS $(3 \mathrm{~mL})$ and metabolites were extracted with cold $\mathrm{MeOH}(80 \%$, containing stds, $1 \mathrm{~mL})$. The $80 \%$ methanolic solution contained dopamine-d4, melatonin-d4 (both Santa Cruz Biotechnology, Dallas, TX, USA) and N-acetylserotonin-d3 (Toronto Research Chemicals BIOZOL) as internal standards at concentrations of $100 \mathrm{pg} \mu \mathrm{L}^{-1}$. Each flask was processed at a time and immediately snap-frozen in liquid nitrogen. Three replicates per condition were then thawed together and the cells were scraped, transferred into labelled Eppendorf tubes and were stored at $-80{ }^{\circ} \mathrm{C}$. Samples were dried and reconstituted in $120 \mu \mathrm{L}$ of $1 \%$ methanol and $0.2 \%$ formic acid and $1 \mathrm{pg} \mu \mathrm{L}^{-1}$ caffeine-(trimethyl-D9) (Sigma Aldrich) and transferred into HPLC vials equipped with a $200 \mu \mathrm{L}$ V-shape glass insert (both Macherey-Nagel GmbH Co. KG) suitable for LC-MS/MS analysis. Caffeine-(trimethyl-d9) $\left(1 \mathrm{pg} \mu \mathrm{L}^{-1}\right)$ was used as an additional internal standard. Again, the experiment was carried out in biological triplicates.

Data acquisition: Samples were separated on a reversed phase Kinetex XB-C18 column $(2.6 \mu \mathrm{m}, 150 \times 2.1 \mathrm{~mm}, 100 \AA$ A Phenomenex Inc., Torrance, CA, USA) using a Vanquish UHPLC System (Thermo Fisher Scientific). Mass spectrometric analysis was performed on a Q Exactive HF orbitrap (Thermo Fisher Scientific). Mobile phase A consisted of water with $0.2 \%$ formic acid, mobile phase B of methanol with $0.2 \%$ formic acid and the following 
gradient program was run: 1 to $5 \%$ B in $0.5 \mathrm{~min}, 5$ to $40 \%$ B from $0.5-5 \mathrm{~min}$, then 40 to $90 \%$ B from 5-8 min, followed by a wash phase at $90 \%$ B for $2.5 \mathrm{~min}$ and then an equilibration phase at $1 \%$ B for $2 \mathrm{~min}$, yielding a total run-time of $12.5 \mathrm{~min}$. Flow rate was $0.5 \mathrm{~mL} \mathrm{~min}^{-1}$, injection volume was $5 \mu \mathrm{L}$ and the column temperature was set to $40{ }^{\circ} \mathrm{C}$. The injection needle was washed in between runs with $10 \%$ methanol. All samples were analyzed in technical replicates. Samples were analyzed in positive, as well as in negative ionization mode. Scan range was from $m / z$ 100-1000 and resolution was set to 60,000 (at $\mathrm{m} / \mathrm{z} 200$ ) for MS1 and 15,000 (at $m / z 200$ ) for MS2. The four most abundant ions of the full scan were selected for further fragmentation in the HCD collision cell applying $30 \mathrm{eV}$ normalized collision energy. Dynamic exclusion was applied for $6 \mathrm{~s}$. Instrument control was performed using Xcalibur 4.0 Qual browser (Thermo Fisher Scientific).

Data analysis: Raw files generated by the Q Exactive HF were loaded into the Compound Discoverer Software 3.1 (Thermo Fisher Scientific). Compounds were identified in Compound Discoverer with a user workflow tree. A maximum retention time shift of $0.1 \mathrm{~min}$ was allowed for aligning features and using a maximal mass tolerance of $5 \mathrm{ppm}$. Metabolites were matched against mzcloud (Copyright (C) 2021-2020 HighChem LLC, Slovakia mzCloud is a trademark of HighChem LLC, Bratislava, Slovakia). Compounds with a match factor $\geq 80$ were manually checked. This was performed with Xcalibur 4.0 Qual browser (ThermoFisher Scientific). For peak integration and calculation of peak areas, the Tracefinder Software 4.1 (ThermoFisher Scientific) was used. The generated batch table was exported and further processed with Microsoft Excel, GraphPad Prism (Version 6.07) and the Perseus software (Version 1.6.12).

\subsection{Cell Cycle Analysis}

Flow cytometry was performed to determine the cell cycle distribution with and without inflammatory stimulation. Therefore, BD Cycletest ${ }^{\mathrm{TM}}$ Plus DNA Kit (BD Biosciences, Vienna, Austria) was used according to the manufacturer's protocol to prepare the cells and measured on a CytoFLEX Flow Cytometer (Beckman\&Coulter, Vienna, Austria) in the PE-channel. Statistical significance was evaluated with a bidirectional student $t$-test and three biological replicates.

\section{Results}

Macrophages can stimulate endometriotic cells by secreting cytokines such as TNF $\alpha$ and IL1 $\beta$ [24,25]. Here, an in-vitro model of endometriosis was investigated to evaluate the effects of such inflammatory stimuli on endometriotic cells by means of a multi-omics approach, including untargeted shotgun proteomics, metabolomics and eicosanoid analysis (Figure S1). The endometriotic $12-\mathrm{Z}$ cell line was treated with TNF $\alpha$ or IL1 $\beta$ at $10 \mathrm{ng} \mathrm{mL} \mathrm{m}^{-1}$ for $48 \mathrm{~h}$ (Figure 1A). Flow cytometry analysis showed a slight increase in the tetraploid G2/M phase, as well as S-Phase and a corresponding decrease of cells in G0/G1 phase (Figure S2).

\subsection{Eicosanoid Analysis Reveals the Uptake of Eicosanoid Precursors by 12-Z Cells from the Growth Medium}

Eicosanoids from the supernatants of control and inflammatory stimulated $12-Z$ cells were enriched by a solid-phase extraction protocol and subsequently analyzed by mass spectrometry. A total of 49 eicosanoids and polyunsaturated fatty acids (PUFAs) were detected in the supernatants. The composition of the fully supplemented medium was additionally verified. The epithelial-like $12-Z$ cells efficiently depleted the growth medium of the eicosanoid precursors arachidonic acid (AA), docosahexaenoic acid (DHA) and eicosapentaenoic acid (EPA) irrespective of treatment condition (Figure S2). Strikingly, EPA was not detectable after culturing the cells for $48 \mathrm{~h}$. In contrast, the mono-oxygenated hydroxyeicosatetraenoic acids 16-HETE and 18-HETE were not detected in the growth medium, but only in the presence of the cultured cells. Inflammatory stimulation had little impact on the differential expression of eicosanoids. 


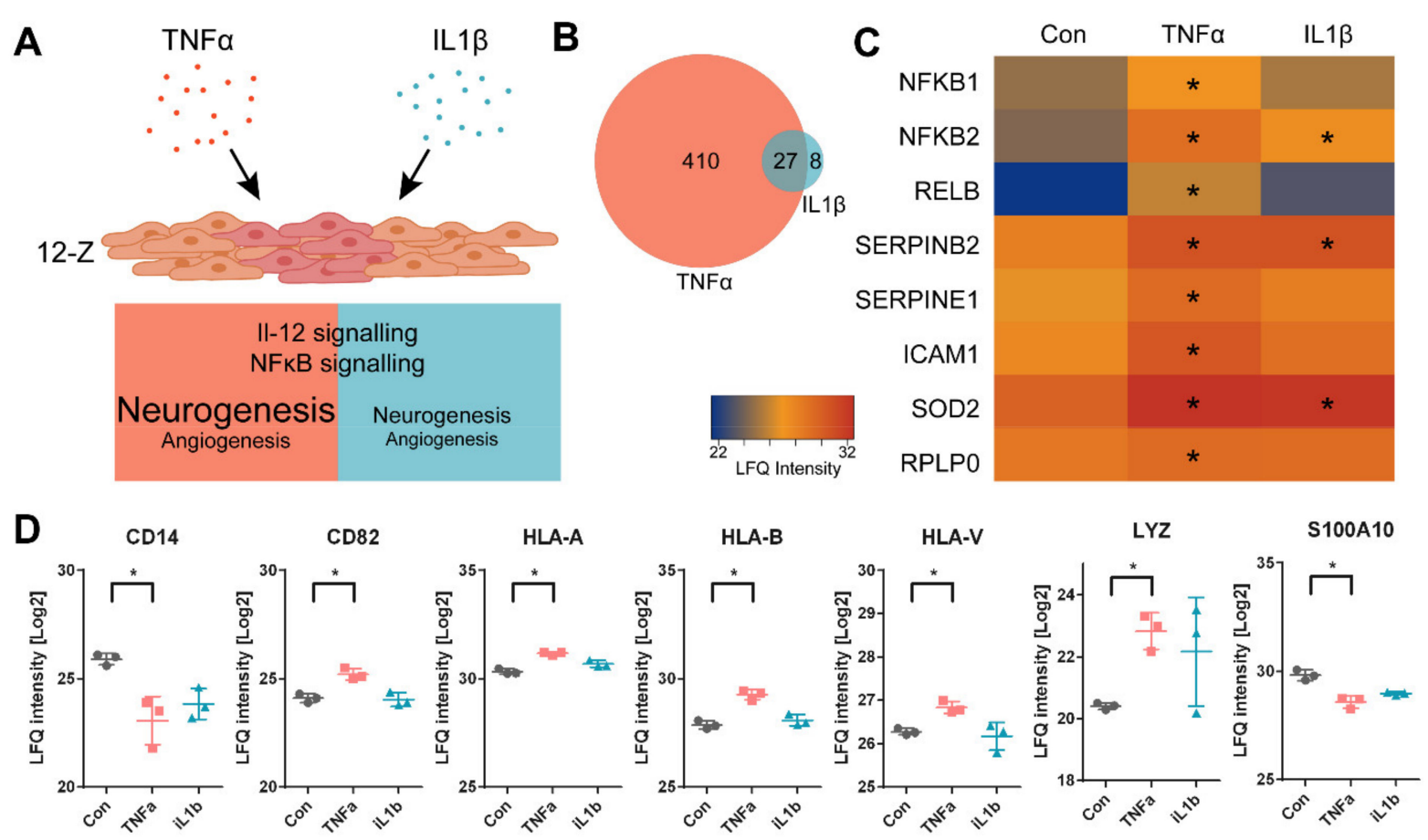

Figure 1. (A) Schematic representation of endometriotic $12-Z$ cells treated with TNF $\alpha$ (red) or IL1 $\beta$ (blue). IL-12 and NF- $\mathrm{B}$ signaling was induced in both treatments while neuroangiogenesis was much more pronounced for TNF $\alpha$ stimulation. (B) Venn-Diagram showing the number of significantly regulated proteins (FDR $=0.05, \mathrm{~S} 0=0.1$ ) for TNF $\alpha$ (red) and IL1 $\beta$ (blue) compared to the control state. Twenty-seven protein groups were significantly regulated in both treatments. (C) Heatmap highlighting proteins involved in NF-kB and Il-12 signaling and downstream targets. (D) Protein signature characteristic for the phenotype of intermediate monocytes upon treatment of epithelial-like 12-Z cells with TNF $\alpha$ (red) and not with IL1 $\beta$ (blue). Asterisks $\left(^{*}\right)$ show multi-parameter corrected significant regulations of protein abundance $($ FDR $=0.05$, $\mathrm{S} 0=0.1)$ compared to untreated controls (Con).

3.2. TNF $\alpha$ - and IL1 $\beta$-Stimulated 12-Z Cells Show Enhanced Proliferation and Activation of IL-12 and NF- $\kappa B$ Signaling Pathways

Proteomic profiling was performed on the cytoplasmic (soluble) fraction and resulted in the identification of 3684 protein groups. Label-free quantification (LFQ) was used to compare inflammatory stimulated with untreated conditions. In LFQ proteomics, the unlabeled peptides are quantified on the MS1 level and the intensities were adjusted to the overall intensity of all quantified peptides. Multi-parameter corrected statistical analysis $(\mathrm{FDR}=0.05, \mathrm{~S} 0=0.1$ ) revealed 437 and 35 significantly regulated proteins after treatment with TNF $\alpha$ or IL1 $\beta$, respectively, while 27 protein groups were regulated in both treatments (Figure 1B). Thus, inflammatory stimulation of $12-Z$ cells by TNF $\alpha$ led to 10 -fold higher number of significantly regulated proteins compared to stimulation by IL1 $\beta$. The most prominent regulations confirmed a successful inflammatory stimulation of the cells by upregulating IL-12 and NF- KB signaling pathways (Figure 1A). Upon TNF $\alpha$ treatment the classical (NFKB1) and alternative (NFKB2, RELB) NF- $\kappa$ B pathways were significantly upregulated while IL1 $\beta$ triggered partly the alternative pathway [51]. Both treatments, however, significantly induced the expression of downstream IL-12 and NF- $\mathrm{B}$ targets (i.e., SOD2, SERPINB2) as exemplified in the heatmap in Figure 1C. Intermediate monocytes are a subpopulation of monocytes characterized by antigen presentation and transendothelial migration [52]. In contrast to classical monocytes, intermediate monocytes feature lower CD14 levels, but increased antigen presentation (HLA), lysozyme, S100A8 and S100A10 as identified by transcriptomic profiling. We found a strikingly similar protein signature corresponding to this intermediate monocyte state for the TNF $\alpha$-treated, but not the IL1 $\beta$-treated 12-Z cells (Figure 1D). 


\subsection{TNF $\alpha$ Induces the Expression of Proteins Involved in Neuroangiogenesis in $12-\mathrm{Z}$ Cells}

$\mathrm{TNF} \alpha$ stimulation showed the upregulation of several proteins involved in neuroangiogenesis. For example, regulated protein groups revealed dorsal root ganglion morphogenesis, sensory neuron axon guidance, neuron projection extension/guidance, semaphorin signaling and positive regulation of sprouting angiogenesis (Figure 2A). ClueGo analysis of significantly regulated proteins further revealed a network corresponding to angiogenesis, including amongst others the VEGF pathway (Figure 2B). Furthermore, the neuropilin receptors NRP1/NRP2 and RPL10 were found to be significantly upregulated [53]. STRING network analysis revealed a strong interconnection of proteins associated with neuroangiogenesis, which were significantly upregulated upon treatment with $T N F \alpha$, including angiogenesis promoters ICAM1, VCAM1 [54], and ITGA5 [55] (Figure 2C). Furthermore, downstream targets of vascular endothelial growth factor (VEGF) signaling have been found upregulated upon stimulation with TNF $\alpha$ (e.g., BCRA1, ITGAV). A significant upregulation of proteins involved in semaphorin signaling was observed (e.g., OPTN, EPHA4, DHRS3). While none of the described proteins were significantly upregulated by IL1 $\beta$ treatment, they showed a similar trend, which highlighted the differential responses of these endometriotic cells to distinct inflammatory stimulations.
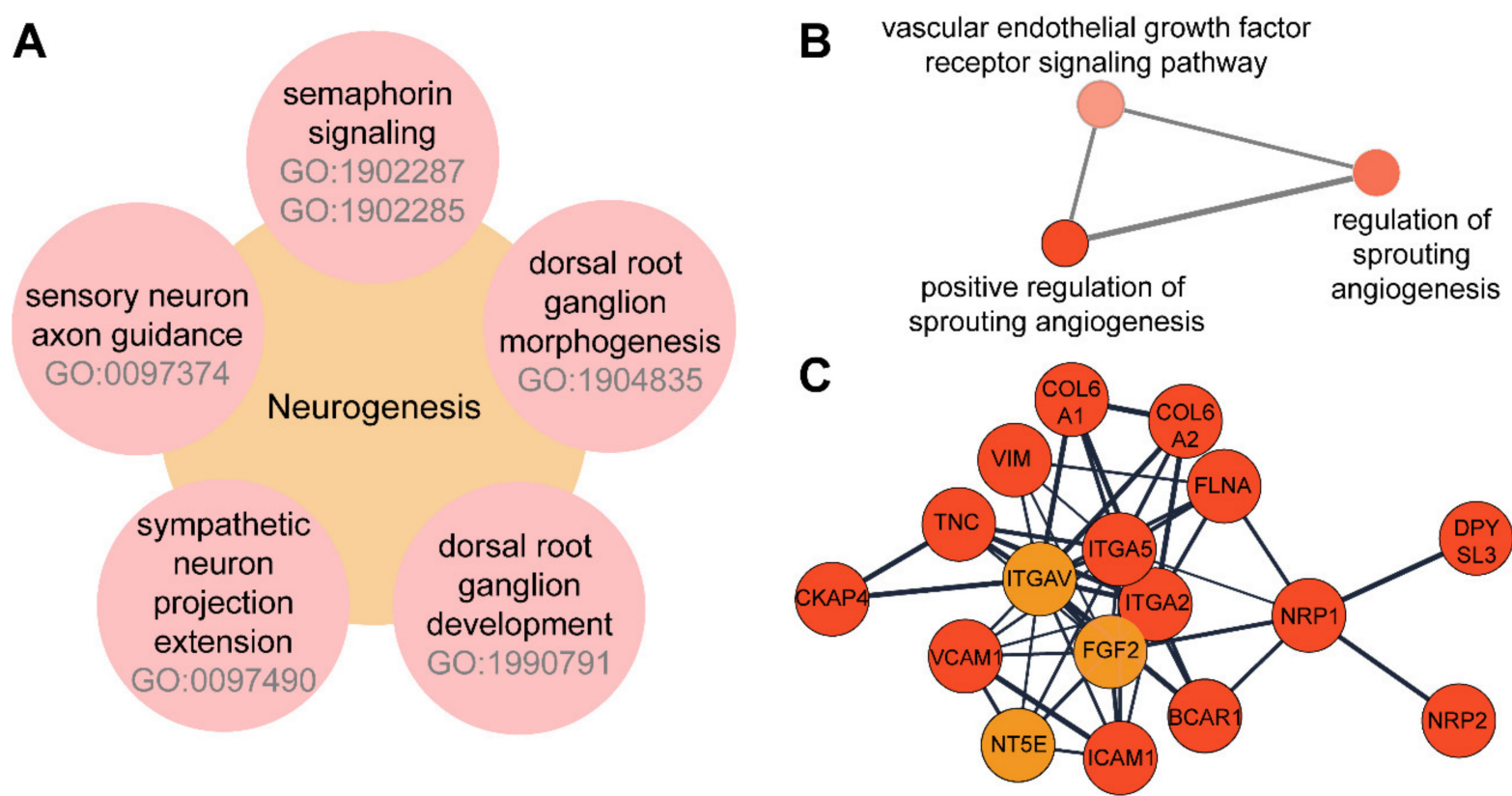

Figure 2. (A) Gene Ontology terms for biological processes (GOBP) associated with neurogenesis. (B) ClueGo network for angiogenesis. (C) STRING network analysis for proteins involved in neurogenesis and angiogenesis. Red indicates multiparameter corrected significant regulation while yellow-colored proteins show higher expression but are not significant.

\subsection{Untargeted Metabolomics Reveals the Upregulation of 7,8-Dihydroneopterin, 7,8-Dihydrobiopterin (BH2) and Normetanephrine in 12-Z Cells}

The signature of upregulated proteins involved in neuroangiogenesis and neuropathic pain motivated the investigation of pain-associated signaling molecules on the level of metabolites. For this purpose, an untargeted metabolomics assay was carried out by collecting whole cell lysates and supernatants of control and inflammatory stimulated $12-Z$ cells. Additionally, the fully supplemented medium was analyzed using the same method to determine the composition of the metabolic background similarly to the eicosanoid analysis. The experiment included a database search based on $\mathrm{MS}^{2}$ fragment spectra which resulted in the identification of 29,607 features, from which the software annotated 633 compounds with a match factor $\geq 80$ (Table S3). After manual review, 63 metabolites were selected and their abundances were quantified on $\mathrm{MS}^{1}$ level as area under the curve based on accurate masses and retention time (Table S2). Multi-parameter corrected statis- 
tical analysis ( $F D R=0.05, \mathrm{~S} 0=0.1)$ revealed 15 and 4 significantly regulated metabolites for TNF $\alpha$ and IL1 $\beta$ in the whole cell lysates, respectively (Figure 3A). An analogous analysis of the supernatants revealed 3 and 26 significantly regulated metabolites for $\mathrm{TNF} \alpha$ and IL1 $\beta$ treatments, respectively (Figure 3B). Strikingly, 7,8-dihydroneopterin, 7,8-dihydrobiopterin (BH2), epinephrine (identity of the molecule verified with external standards) and normetanephrine (annotated based on $\mathrm{MS}^{2}$ ) were detected in endometriotic $12-Z$ cells (Figures 3 and 4 ). These metabolites were not detected in the fully supplemented cell culture medium (Figure S3), but only in whole cell extracts and supernatants only in the presence of the $12-\mathrm{Z}$ cells (Figure $4 \mathrm{~A}$ ). The recorded fragmentation spectra matched well the reference spectra from mzcloud database and corroborated the identification of these molecules (Figure 4B). In fact, BH2 and normetanephrine were significantly upregulated in the cellular interior during inflammatory stimulation with TNF $\alpha$ or IL1 $\beta$, while 7,8-dihydroneopterin was upregulated upon TNF $\alpha$ stimulation only (Figures 3 and 4). The induction of $\mathrm{BH} 2,7,8$-dihydroneopterin and normetanephrine was more pronounced upon activation with TNF $\alpha$ compared to IL1 $\beta$. Interestingly, the enzymes involved in the biosynthesis of these metabolites remained largely constant upon inflammatory stimulation (e.g., dihydrofolate reductase DHFR or catechol O-methyltransferase COMT), with the exception of sepiapterin reductase (SPR), which was down-regulated by TNF $\alpha$ treatment (Figure 4). Epinephrine and normetanephrine were unexpectedly detected in $12-Z$ cells, as they were not yet associated with these endometriotic epithelial-like cells.
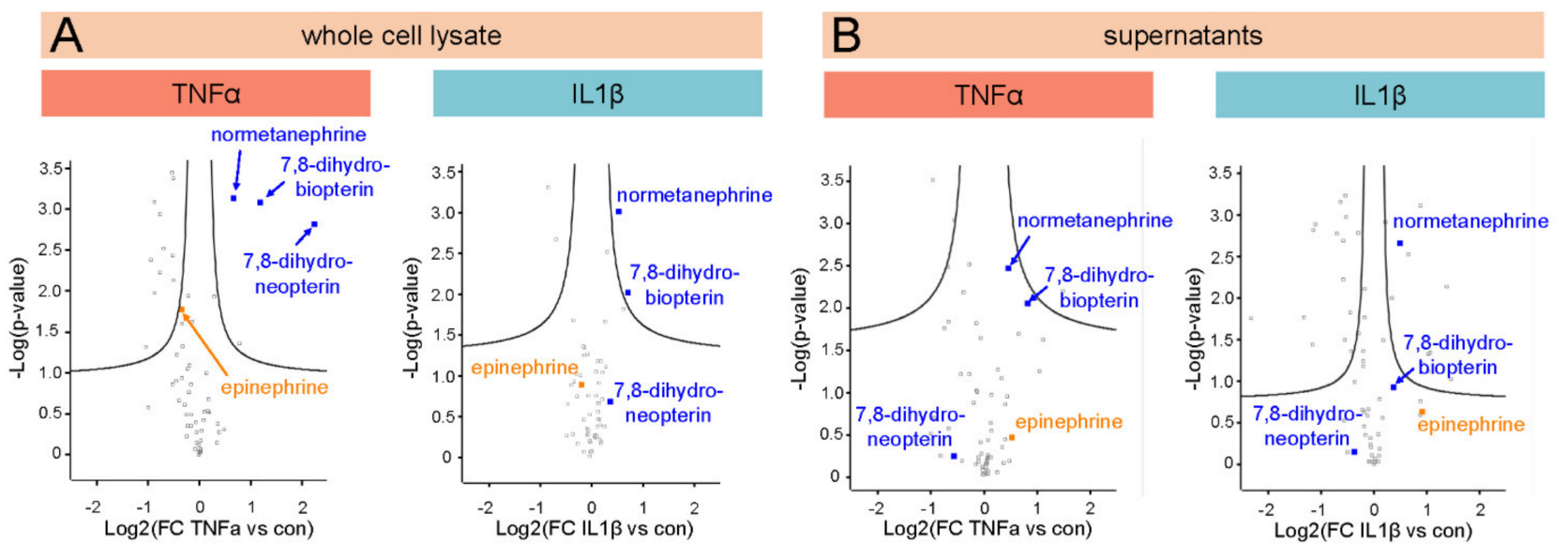

Figure 3. Volcano plots comparing metabolite profiles of control experiments with TNF $\alpha$ and IL1 $\beta$ treatments in whole cell lysates (A) and supernatants (B). X-axis displays the calculated difference of treatment-control an a log2-scale and $\mathrm{y}$-axis show the - $\log \mathrm{p}$-value for each molecule. Metabolites above significance curves represent multi-parameter corrected significantly regulated metabolites $(\mathrm{FDR}=0.05, \mathrm{~S} 0=0.1)$. 
A

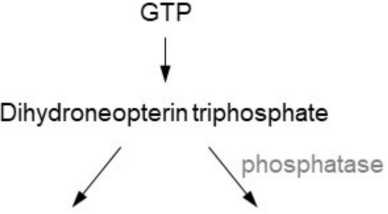

6-pyruvoyl tetrahydropterin 7,8-dihydroneopterin

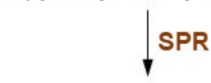

5,6,7,8-tetrahydrobiopterin

DHFR

7,8-dihydrobiopterin

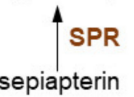

7,8-dihydrobiopterin 7,8-dihydroneopterin
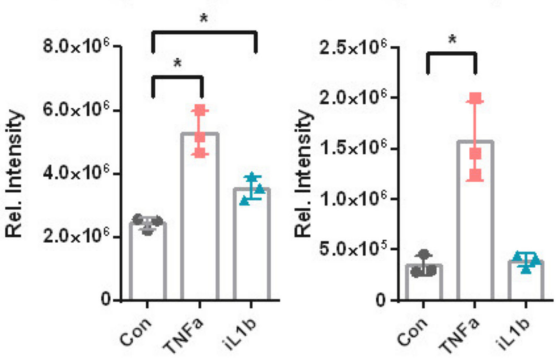

7,8-dihydroneopterin
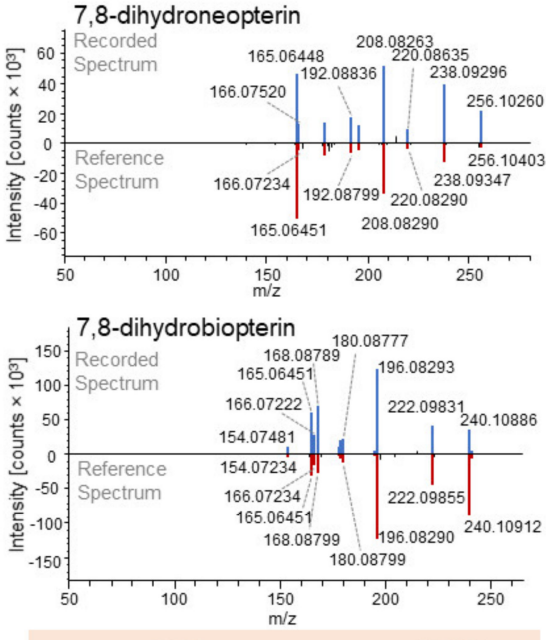

SPR

DHFR

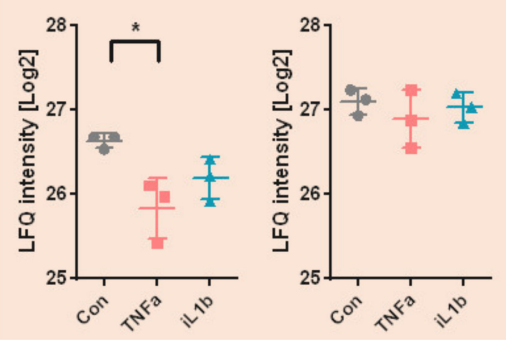

B
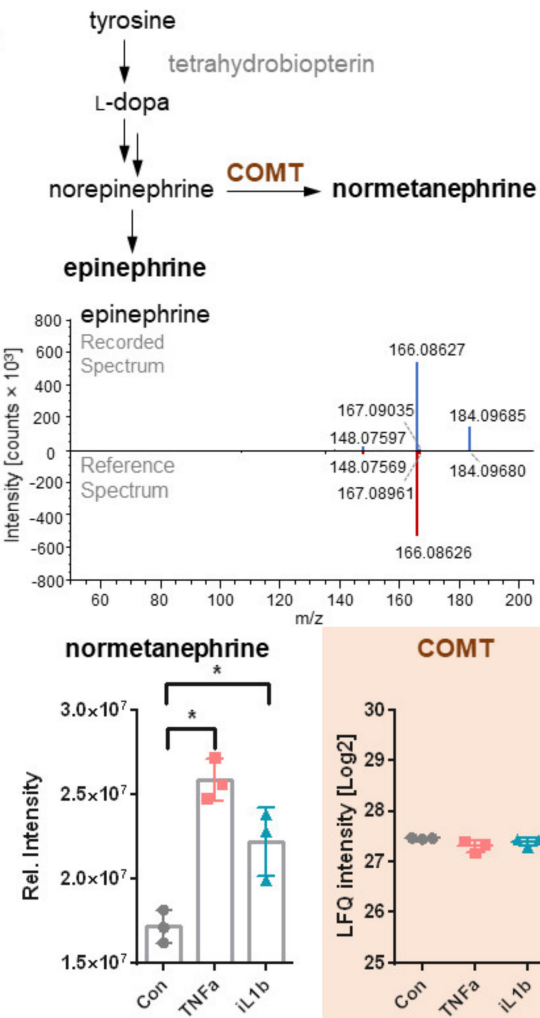

СOMT

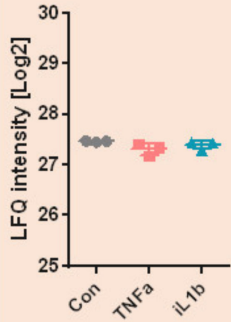

Figure 4. (A) The metabolic pathway for the synthesis of 7,8-dihydroneopterin and 7,8-dihydrobiopterin is depicted together with the MS 2 spectra of the measured metabolites compared to the reference spectrum from the mzcloud database. Intensity values of the metabolite and protein levels (orange background) in control, as well as TNF $\alpha$ - and IL1 $\beta$-treatment, are given below. (B) Biosynthetic pathway of epinephrine derivatives. Normetanephrine is obtained from norepinephrine by the catechol-O-methyl transferase (COMT). $\mathrm{MS}^{2}$ spectra of normetanephrine compared to the reference spectrum from the mzcloud database. Intensity values of the metabolite and protein levels (orange background) in control, as well as TNF $\alpha-$ and IL1 $\beta$-treatment, are given below. None of the metabolites were detected in the fully supplemented medium (Figure S3). Asterisks $\left(^{*}\right)$ show multi-parameter corrected significant regulations of metabolite intensities compared to untreated controls $(\mathrm{FDR}=0.05, \mathrm{~S} 0=0.1)$. The orange shadows distinguish the abundance changes of proteins from those of the metabolites.

\section{Discussion}

Although endometriosis is affecting the quality of life of millions of women worldwide, representing a clear unmet medical need, the underlying molecular mechanism of this disease remains largely unknown. As pain sensation is among the most prevalent symptoms, investigating molecular mechanisms responsible for the development of pain may be key to identify useful therapeutic approaches. The interplay among endometriotic cells, macrophages and nerve cells in the ectopic lesions of endometriosis is of special interest for the origin of pain. We performed a multi-omics analysis, including proteomics, metabolomics and eicosanoid analysis, of the epithelial-like $12-Z$ endometriotic cell line in order to characterize the responses of these cells to inflammatory stimulation and their potential involvement in the development of pain. The $12-\mathrm{Z}$ endometriotic cells were previously characterized as a proliferating and invasive cell line [38]. We found that inflammatory stimulation with TNA $\alpha$ or IL1 $\beta$ did not greatly affect the cell cycle distribution compared to untreated cells. In accordance, the eicosanoid precursors AA, DHA and EPA were efficiently depleted from growth medium irrespective of the inflammatory stimulus and were probably incorporated in the membranes of $12-\mathrm{Z}$ cells. The mono-oxygenated 16- and 18-HETE are cytochrome P450 metabolic products of AA and were released from $12-Z$ cells. Importantly, 16-HETE is typically generated by exposure of resting neutrophils to AA [56] and represents an endogenous inhibitor of neutrophil activation [57] and thus 
exhibits anti-inflammatory effects. In our setup, the extent of 16-HETE release was independent of treatment condition.

The proteomic data suggested that the $12-\mathrm{Z}$ endometriotic cells, when stimulated with $\mathrm{TNF} \alpha$, may mimic an intermediate monocytic phenotype, which is generally characterized by transendothelial migration [52], and is actively involved in forming and sustaining a neuroangiogenic microenvironment characteristic for endometriotic lesions. Endometriotic cells were previously shown to exhibit enhanced migratory properties upon exposure to proinflammatory factors [9-11]. Moreover, dysfunction in macrophage-mediated phagocytosis of endometrial cells that undergo retrograde transport to the peritoneal cavity is considered an important factor in the development of endometriosis. In fact, this mimicry phenotype of the $12-Z$ cells may contribute towards the dysregulated immune clearance observed in endometriosis $[14,15]$. Generally, the $12-Z$ cells seem more susceptible towards stimulation by TNF $\alpha$ compared to IL1 $\beta$. Inflammatory stimulation led to the upregulation of proteins involved in neuronal interactions as well as dorsal root ganglion morphogenesis and axon guidance. It is known that the pathology of endometriosis features neuronal interactions and especially neurogenesis [22]. Furthermore, a previous study already showed differential expression of semaphorins and neuropilin receptors correlating to dysmenorrhea [58]. Semaphorins are a group of evolutionarily highly conserved surface or locally secreted nerve repellent factors that can regulate axon migration, axonal growth and guidance [59-61]. The potential role of semaphorin 3A and its receptor (NRP1) in the regulation of aberrant sympathetic innervation in peritoneal endometriosis have been previously described [58]. Neuropilin receptors are prominent neurogenesis promoters, which function as axon guidance signaling receptors, as well as angiogenesis activation [31]. Our study shows that stimulation of $12-Z$ cells with TNF $\alpha$ upregulates the levels of NRP1, NRP2, DPYSL3, OPTN, EPHA4 and DHRS3 proteins suggesting an active involvement of endometriotic epithelial cells in semaphorin signaling. Normally, the process of nervous generation is a conserved feature present during embryonic development [62]. Although proteins like RPL10 and NRP1/2 are mostly associated with embryonic developmental signaling, they have been found significantly overexpressed upon TNF $\alpha$ stimulation in $12-Z$ in this study and suggest an unrecognized functional plasticity of these cells, which may contribute towards an increased understanding of this pathology.

We further combined the proteome profiling with untargeted metabolomic analysis, investigating whether metabolites of $12-Z$ cells may be able to contribute to neuronal interaction and signaling. Especially, the capability of the production of 7,8-dihydrobiopterin (BH2), 7,8-dihydroneopterin, epinephrine and normetanephrine by endometriotic epithelial cells was striking. The differential expression of these metabolites was not correlated with the corresponding enzymes in their biosynthetic pathways (Figure 4). 7,8-Dihydroneopterin is an accepted metabolic inflammation marker normally generated by macrophages and has been related to impaired phagocytosis in endometriosis patients [14,63]. Epinephrine is a neurotransmitter secreted by the adrenal medulla. It is required for the vagus-mediated modulation of the nociceptive threshold and acts as inflammatory mediator induced in hyperalgesia [64]. Norepinephrine, the epinephrine precursor, from sympathetic nerve fibers is known to bind the oestradiol $\mathrm{B} 2$ receptor on macrophages, leading to activation of PKA signaling and thus stimulating TNF $\alpha$ mediated inflammation [27]. Norepinephrine is generally involved in inflammation as well as endometriosis pathology [18,65]. This mechanism was previously described as an interaction between nerve cells and macrophages. The deregulation of epinephrine and semaphoring/NRP1 signaling pathways in the nerve cells of endometriosis lesion has been shown to support macrophage polarization [66-68]. Our data, however, suggest that epithelial endometriotic cells might themselves be capable of producing these metabolites, subsequently leading to enhanced TNF $\alpha$ secretion by polarized macrophages.

The present model proposes not only a potential influence of endometriosis-associated epithelial cells on macrophages but on nerve cells as well. The significant upregulation of neurogenesis-related proteins demonstrated that the $12-\mathrm{Z}$ cells may be capable of 
independently modulating neuronal mechanisms. Here again, norepinephrine and its metabolites might play an important role in the activation of pain [69]. It has been shown that epinephrine activates unmyelinated afferents in lesioned nerves [70]. Since endometriotic lesions contain large amounts of unmyelinated nerve fibres [71], there might be a connection between epinephrine secretion and the induction of pain sensation. The detection of epinephrine and normetanephrine in cell lysates and supernatants of IL1 $\beta$-activated endometriotic cells is unprecedented, since this metabolite is normally produced by adrenal glands. Thus, TNF $\alpha$ and IL1 $\beta$ activation might be important to perpetuate the disease by affecting proteome, metabolome and eicosanoid levels differentially. Finally, the conversion of tetrahydrobiopterin (BH4) into $\mathrm{BH} 2$ is involved in the biosynthesis of norepinephrine as the initial hydroxylation step from tyrosine [72]. BH4 application in vivo has been shown to cause heat hypersensitivity and increased pain sensation through TRPV1 [73]. TRPV1 receptor is overexpressed in ectopic endometriosis implants, as well as in dorsal root ganglia of rats with endometriosis [12,74].

\section{Conclusions}

In summary, the data presented in this work highlights the proteomic, metabolomic and eicosanoid alterations upon inflammatory stimulation of the endometriotic epitheliallike cell line 12-Z. Besides the expected activation of inflammatory signaling cascades upon cytokine stimulation, these cells displayed an unexpected protein signature related to neuroangiogenesis which clearly underlined their capability to support neurogenesis in the lesion. Putative novel mediators in endometriosis pathology and pain development were discovered on the protein, metabolite and eicosanoid levels. This study indicates that $12-Z$ endometriotic cells may mimic an intermediate monocytic phenotype and actively participate in the crosstalk of the macrophage-nervous network within the lesion on the protein and metabolite levels. Thus, inflammatory stimulation of endometriotic cells by TNF $\alpha$ and IL1 $\beta$ seem to play an important role in the perpetuation of the characteristic inflammatory phenotype. They further seem to create factors enhancing the pain sensation through neurogenic inflammation. The actual interaction of endometriotic cells with macrophages and nerve cells requires further investigation but the presented data provided experimental evidence that they might be capable of hijacking immune cell functions in order to support the development and growth of an endometriotic lesion outside the uterine cavity.

Supplementary Materials: The following supplementary information is available online at https: //www.mdpi.com/article/10.3390/biom11081230/s1: Figure S1: Schematic experimental setup, Figure S2: Cell cycle analysis and selected eicosanoids, Figure S3: Extracted ion chromatograms of selected metabolites; Table S1: Results from proteomic analysis, Table S2: Results from metabolomics analysis.

Author Contributions: Conceptualisation, B.N., M.L., I.Y. and C.G.; Investigation, B.N., M.L., J.B., G.H., L.S. and M.C.G.; Formal analysis, B.N., M.L., J.B., G.H. and M.C.G.; Resources, I.Y. and C.G.; Validation, S.M.M.-M., C.G.; Visualisation, B.N., M.L. and S.M.M.-M.; Writing-original draft, B.N., M.L.; Writing-review \& editing, S.M.M.-M., I.Y., C.G. All authors have read and agreed to the published version of the manuscript.

Funding: Open Access Funding by the University of Vienna.

Data Availability Statement: The mass spectrometry proteomics data were deposited in the ProteomeXchange Consortium (http:/ / proteomecentral.proteomexchange.org) via the PRIDE partner repository [39] with the dataset identifier PXD022354 and 10.6019/PXD022354.

Acknowledgments: The authors are grateful to the Core Facility of Mass Spectrometry at the Faculty of Chemistry, University of Vienna and the Joint Metabolome Facility, University of Vienna and Medical University of Vienna. Both facilities are members of the Vienna Life-Science Instruments (VLSI).

Conflicts of Interest: The authors declare no conflict of interest. 


\section{References}

1. Sonavane, S.K.; Kantawala, K.P.; Menias, C.O. Beyond the boundaries-endometriosis: Typical and atypical locations. Curr. Probl. Diagn. Radiol. 2011, 40, 219-232. [CrossRef] [PubMed]

2. Renner, S.P.; Strissel, P.L.; Beckmann, M.W.; Lermann, J.; Burghaus, S.; Hackl, J.; Fasching, P.A.; Strick, R. Inhibition of adhesion, proliferation, and invasion of primary endometriosis and endometrial stromal and ovarian carcinoma cells by a nonhyaluronan adhesion barrier gel. Biomed. Res. Int. 2015, 2015, 450468. [CrossRef] [PubMed]

3. McKinnon, B.D.; Kocbek, V.; Nirgianakis, K.; Bersinger, N.A.; Mueller, M.D. Kinase signalling pathways in endometriosis: Potential targets for non-hormonal therapeutics. Hum. Reprod. Update 2016, 22, 382-403. [CrossRef] [PubMed]

4. Imanaka, S.; Maruyama, S.; Kimura, M.; Nagayasu, M.; Kobayashi, H. Towards an understanding of the molecular mechanisms of endometriosis-associated symptoms (Review). World Acad. Sci. J. 2020, 2, 12. [CrossRef]

5. Haas, D.; Shebl, O.; Shamiyeh, A.; Oppelt, P. The rASRM score and the Enzian classification for endometriosis: Their strengths and weaknesses. Acta Obstet. Gynecol. Scand. 2013, 92, 3-7. [CrossRef]

6. Morotti, M.; Vincent, K.; Becker, C.M. Mechanisms of pain in endometriosis. Eur. J. Obstet. Gynecol. Reprod. Biol. 2017, 209, 8-13. [CrossRef]

7. Zhang, X.; Yao, H.; Huang, X.; Lu, B.; Xu, H.; Zhou, C. Nerve fibres in ovarian endometriotic lesions in women with ovarian endometriosis. Hum. Reprod. 2010, 25, 392-397. [CrossRef]

8. Walch, K.; Kernstock, T.; Poschalko-Hammerle, G.; Gleiss, A.; Staudigl, C.; Wenzl, R. Prevalence and severity of cyclic leg pain in women with endometriosis and in controls-Effect of laparoscopic surgery. Eur. J. Obstet. Gynecol. Reprod. Biol. 2014, $179,51-57$. [CrossRef]

9. Porpora, M.G.; Koninckx, P.R.; Piazze, J.; Natili, M.; Colagrande, S.; Cosmi, E.V. Correlation between endometriosis and pelvic pain. J. Am. Assoc. Gynecol. Laparosc. 1999, 6, 429-434. [CrossRef]

10. Bloski, T.; Pierson, R. Endometriosis and Chronic Pelvic Pain: Unraveling the Mystery Behind this Complex Condition. Nurs. Womens Health 2008, 12, 382-395. [CrossRef]

11. Klemmt, P.A.B.; Starzinski-Powitz, A. Molecular and Cellular Pathogenesis of Endometriosis. Curr. Womens Health Rev. 2018, 14, 106-116. [CrossRef] [PubMed]

12. Lian, Y.L.; Cheng, M.J.; Zhang, X.X.; Wang, L. Elevated expression of transient receptor potential vanilloid type 1 in dorsal root ganglia of rats with endometriosis. Mol. Med. Rep. 2017, 16, 1920-1926. [CrossRef]

13. Izumi, G.; Koga, K.; Takamura, M.; Makabe, T.; Satake, E.; Takeuchi, A.; Taguchi, A.; Urata, Y.; Fujii, T.; Osuga, Y. Involvement of immune cells in the pathogenesis of endometriosis. J. Obstet. Gynaecol. Res. 2018, 44, 191-198. [CrossRef]

14. Chuang, P.C.; Wu, M.H.; Shoji, Y.; Tsai, S.J. Downregulation of CD36 results in reduced phagocytic ability of peritoneal macrophages of women with endometriosis. J. Pathol. 2009, 219, 232-241. [CrossRef]

15. Herington, J.L.; Bruner-Tran, K.L.; Lucas, J.A.; Osteen, K.G. Immune interactions in endometriosis. Expert Rev. Clin. Immunol. 2011, 7, 611-626. [CrossRef] [PubMed]

16. Dmowski, W.P.; Gebel, H.M.; Braun, D.P. The role of cell-mediated immunity in pathogenesis of endometriosis. Acta Obstet. Gynecol. Scand. Suppl. 1994, 159, 7-14.

17. Nanda, A.; Thangapandi, K.; Banerjee, P.; Dutta, M.; Wangdi, T.; Sharma, P.; Chaudhury, K.; Jana, S.K. Cytokines, Angiogenesis, and Extracellular Matrix Degradation are Augmented by Oxidative Stress in Endometriosis. Ann. Lab. Med. 2020, $40,390-397$. [CrossRef] [PubMed]

18. Liang, Y.; Xie, H.; Wu, J.; Liu, D.; Yao, S. Villainous role of estrogen in macrophage-nerve interaction in endometriosis. Reprod. Biol. Endocrinol. 2018, 16, 122. [CrossRef]

19. Greaves, E.; Temp, J.; Esnal-Zufiurre, A.; Mechsner, S.; Horne, A.W.; Saunders, P.T. Estradiol is a critical mediator of macrophagenerve cross talk in peritoneal endometriosis. Am. J. Pathol. 2015, 185, 2286-2297. [CrossRef] [PubMed]

20. Capobianco, A.; Rovere-Querini, P. Endometriosis, a disease of the macrophage. Front. Immunol. 2013, 4, 9. [CrossRef]

21. Sondell, M.; Sundler, F.; Kanje, M. Vascular endothelial growth factor is a neurotrophic factor which stimulates axonal outgrowth through the flk-1 receptor. Eur. J. Neurosci. 2000, 12, 4243-4254. [CrossRef] [PubMed]

22. Sheveleva, T.; Bejenar, V.; Komlichenko, E.; Dedul, A.; Malushko, A. Innovative approach in assessing the role of neurogenesis, angiogenesis, and lymphangiogenesis in the pathogenesis of external genital endometriosis. Gynecol. Endocrinol. 2016, 32, 75-79. [CrossRef] [PubMed]

23. Vallve-Juanico, J.; Houshdaran, S.; Giudice, L.C. The endometrial immune environment of women with endometriosis. Hum. Reprod. Update 2019, 25, 564-591. [CrossRef] [PubMed]

24. Weiss, G.; Goldsmith, L.T.; Taylor, R.N.; Bellet, D.; Taylor, H.S. Inflammation in reproductive disorders. Reprod. Sci. 2009, 16, 216-229. [CrossRef]

25. Wang, X.M.; Ma, Z.Y.; Song, N. Inflammatory cytokines IL-6, IL-10, IL-13, TNF-alpha and peritoneal fluid flora were associated with infertility in patients with endometriosis. Eur. Rev. Med. Pharmacol. Sci. 2018, 22, 2513-2518. [CrossRef]

26. Casazza, A.; Laoui, D.; Wenes, M.; Rizzolio, S.; Bassani, N.; Mambretti, M.; Deschoemaeker, S.; Van Ginderachter, J.A.; Tamagnone, L.; Mazzone, M. Impeding macrophage entry into hypoxic tumor areas by Sema3A/Nrp1 signaling blockade inhibits angiogenesis and restores antitumor immunity. Cancer Cell 2013, 24, 695-709. [CrossRef] [PubMed]

27. Wu, J.; Xie, H.; Yao, S.; Liang, Y. Macrophage and nerve interaction in endometriosis. J. Neuroinflamm. 2017, 14, 53. [CrossRef] [PubMed] 
28. Brawn, J.; Morotti, M.; Zondervan, K.T.; Becker, C.M.; Vincent, K. Central changes associated with chronic pelvic pain and endometriosis. Hum. Reprod. Update 2014, 20, 737-747. [CrossRef]

29. Vitonis, A.F.; Vincent, K.; Rahmioglu, N.; Fassbender, A.; Buck Louis, G.M.; Hummelshoj, L.; Giudice, L.C.; Stratton, P.; Adamson, G.D.; Becker, C.M.; et al. World Endometriosis Research Foundation Endometriosis Phenome and Biobanking Harmonization Project: II. Clinical and covariate phenotype data collection in endometriosis research. Fertil. Steril. 2014, 102, 1223-1232. [CrossRef]

30. Song, N.; Leng, J.H.; Lang, J.H. Expression of transient receptor potentials of vanilloid subtype 1 and pain in endometriosis. Zhonghua Fu Chan Ke Za Zhi 2012, 47, 333-336.

31. Hey-Cunningham, A.J.; Peters, K.M.; Zevallos, H.B.; Berbic, M.; Markham, R.; Fraser, I.S. Angiogenesis, lymphangiogenesis and neurogenesis in endometriosis. Front. Biosci. 2013, 5, 1033-1056. [CrossRef]

32. Morotti, M.; Vincent, K.; Brawn, J.; Zondervan, K.T.; Becker, C.M. Peripheral changes in endometriosis-associated pain. Hum. Reprod. Update 2014, 20, 717-736. [CrossRef] [PubMed]

33. Irungu, S.; Mavrelos, D.; Worthington, J.; Blyuss, O.; Saridogan, E.; Timms, J.F. Discovery of non-invasive biomarkers for the diagnosis of endometriosis. Clin. Proteom. 2019, 16, 1-16. [CrossRef]

34. Hudson, Q.J.; Perricos, A.; Wenzl, R.; Yotova, I. Challenges in uncovering non-invasive biomarkers of endometriosis. Exp. Biol. Med. 2020, 245, 437-447. [CrossRef] [PubMed]

35. Ortiz, C.N.; Torres-Reverón, A.; Appleyard, C.B. Metabolomics in endometriosis: Challenges and perspectives for future studies. Reprod. Fertil. 2021, 2, R35-R50. [CrossRef]

36. Khanapure, S.; Garvey, D.; Janero, D.; Gordon Letts, L. Eicosanoids in Inflammation: Biosynthesis, Pharmacology, and Therapeutic Frontiers. Curr. Top. Med. Chem. 2007, 7, 311-340. [CrossRef] [PubMed]

37. Medzhitov, R. Origin and physiological roles of inflammation. Nature 2008, 454, 428-435. [CrossRef] [PubMed]

38. Zeitvogel, A.; Baumann, R.; Starzinski-Powitz, A. Identification of an invasive, N-cadherin-expressing epithelial cell type in endometriosis using a new cell culture model. Am. J. Pathol. 2001, 159, 1839-1852. [CrossRef]

39. Malutan, A.M.; Drugan, T.; Costin, N.; Ciortea, R.; Bucuri, C.; Rada, M.P.; Mihu, D. Pro-inflammatory cytokines for evaluation of inflammatory status in endometriosis. Cent. Eur. J. Immunol. 2015, 40, 96-102. [CrossRef] [PubMed]

40. Neuditschko, B.; Janker, L.; Niederstaetter, L.; Brunmair, J.; Krivanek, K.; Izraely, S.; Sagi-Assif, O.; Meshel, T.; Keppler, B.K.; Del Favero, G.; et al. The Challenge of Classifying Metastatic Cell Properties by Molecular Profiling Exemplified with Cutaneous Melanoma Cells and Their Cerebral Metastasis from Patient Derived Mouse Xenografts. Mol. Cell. Proteom. 2020, 19, 478-489. [CrossRef]

41. Zougman, A.; Selby, P.J.; Banks, R.E. Suspension trapping (STrap) sample preparation method for bottom-up proteomics analysis. Proteomics 2014, 14, 1006-1010. [CrossRef] [PubMed]

42. Mayer, R.L.; Schwarzmeier, J.D.; Gerner, M.C.; Bileck, A.; Mader, J.C.; Meier-Menches, S.M.; Gerner, S.M.; Schmetterer, K.G.; Pukrop, T.; Reichle, A.; et al. Proteomics and metabolomics identify molecular mechanisms of aging potentially predisposing for chronic lymphocytic leukemia. Mol. Cell. Proteom. 2018, 17, 290-303. [CrossRef]

43. Cox, J.; Mann, M. MaxQuant enables high peptide identification rates, individualized p.p.b.-range mass accuracies and proteomewide protein quantification. Nat. Biotechnol. 2008, 26, 1367-1372. [CrossRef] [PubMed]

44. Gerner, M.C.; Niederstaetter, L.; Ziegler, L.; Bileck, A.; Slany, A.; Janker, L.; Schmidt, R.L.J.; Gerner, C.; Del Favero, G.; Schmetterer, K.G. Proteome analysis reveals distinct mitochondrial functions linked to interferon response patterns in activated CD4+ and CD8+ T cells. Front. Pharmacol. 2019, 10, 727. [CrossRef] [PubMed]

45. Bileck, A.; Kreutz, D.; Muqaku, B.; Slany, A.; Gerner, C. Comprehensive assessment of proteins regulated by dexamethasone reveals novel effects in primary human peripheral blood mononuclear cells. J. Proteome Res. 2014, 13, 5989-6000. [CrossRef] [PubMed]

46. Shannon, P.; Markiel, A.; Ozier, O.; Baliga, N.S.; Wang, J.T.; Ramage, D.; Amin, N.; Schwikowski, B.; Ideker, T. Cytoscape: A software environment for integrated models of biomolecular interaction networks. Genome Res. 2003, 13, 2498-2504. [CrossRef]

47. Bindea, G.; Mlecnik, B.; Hackl, H.; Charoentong, P.; Tosolini, M.; Kirilovsky, A.; Fridman, W.H.; Pages, F.; Trajanoski, Z.; Galon, J. ClueGO: A Cytoscape plug-in to decipher functionally grouped gene ontology and pathway annotation networks. Bioinformatics 2009, 25, 1091-1093. [CrossRef] [PubMed]

48. Szklarczyk, D.; Gable, A.L.; Lyon, D.; Junge, A.; Wyder, S.; Huerta-Cepas, J.; Simonovic, M.; Doncheva, N.T.; Morris, J.H.; Bork, P.; et al. STRING v11: Protein-protein association networks with increased coverage, supporting functional discovery in genome-wide experimental datasets. Nucleic Acids Res. 2019, 47, D607-D613. [CrossRef] [PubMed]

49. Perez-Riverol, Y.; Csordas, A.; Bai, J.; Bernal-Llinares, M.; Hewapathirana, S.; Kundu, D.J.; Inuganti, A.; Griss, J.; Mayer, G.; Eisenacher, M.; et al. The PRIDE database and related tools and resources in 2019: Improving support for quantification data. Nucleic Acids Res. 2019, 47, D442-D450. [CrossRef]

50. Fahy, E.; Sud, M.; Cotter, D.; Subramaniam, S. LIPID MAPS online tools for lipid research. Nucleic Acids Res. 2007, 35, W606-W612. [CrossRef]

51. Karin, M.; Greten, F.R. NF-kappaB: Linking inflammation and immunity to cancer development and progression. Nat. Rev. Immunol. 2005, 5, 749-759. [CrossRef]

52. Kapellos, T.S.; Bonaguro, L.; Gemünd, I.; Reusch, N.; Saglam, A.; Hinkley, E.R.; Schultze, J.L. Human Monocyte Subsets and Phenotypes in Major Chronic Inflammatory Diseases. Front. Immunol. 2019, 10, 2035. [CrossRef] [PubMed] 
53. Brooks, S.S.; Wall, A.L.; Golzio, C.; Reid, D.W.; Kondyles, A.; Willer, J.R.; Botti, C.; Nicchitta, C.V.; Katsanis, N.; Davis, E.E. A novel ribosomopathy caused by dysfunction of RPL10 disrupts neurodevelopment and causes X-linked microcephaly in humans. Genetics 2014, 198, 723-733. [CrossRef] [PubMed]

54. Laschke, M.W.; Menger, M.D. Basic mechanisms of vascularization in endometriosis and their clinical implications. Hum. Reprod. Update 2018, 24, 207-224. [CrossRef] [PubMed]

55. Somanath, P.R.; Malinin, N.L.; Byzova, T.V. Cooperation between integrin alphavbeta3 and VEGFR2 in angiogenesis. Angiogenesis 2009, 12, 177-185. [CrossRef]

56. Shoieb, S.M.; El-Sherbeni, A.A.; El-Kadi, A.O.S. Subterminal hydroxyeicosatetraenoic acids: Crucial lipid mediators in normal physiology and disease states. Chem. Biol. Interact. 2019, 299, 140-150. [CrossRef]

57. Kraemer, R.; Bednar, M.M.; Hatala, M.A.; Mullane, K.M. A neutrophil-derived cytochrome P450-dependent metabolite of arachidonic acid modulates neutrophil behavior. Am. J. Pathol. 1987, 128, 446-454. [PubMed]

58. Liang, Y.; Wang, W.; Huang, J.; Tan, H.; Liu, T.; Shang, C.; Liu, D.; Guo, L.; Yao, S. Potential Role of Semaphorin 3A and Its Receptors in Regulating Aberrant Sympathetic Innervation in Peritoneal and Deep Infiltrating Endometriosis. PLoS ONE 2015 10, e0146027. [CrossRef]

59. Koncina, E.; Roth, L.; Gonthier, B.; Bagnard, D. Role of semaphorins during axon growth and guidance. Adv. Exp. Med. Biol. 2007, 621, 50-64. [CrossRef]

60. Markovinovic, A.; Cimbro, R.; Ljutic, T.; Kriz, J.; Rogelj, B.; Munitic, I. Optineurin in amyotrophic lateral sclerosis: Multifunctional adaptor protein at the crossroads of different neuroprotective mechanisms. Prog. Neurobiol. 2017, 154, 1-20. [CrossRef] [PubMed]

61. Hu, S.; Zhu, L. Semaphorins and Their Receptors: From Axonal Guidance to Atherosclerosis. Front. Physiol. 2018, 9, 1236. [CrossRef] [PubMed]

62. Malik, S.; Vinukonda, G.; Vose, L.R.; Diamond, D.; Bhimavarapu, B.B.; Hu, F.; Zia, M.T.; Hevner, R.; Zecevic, N.; Ballabh, P. Neurogenesis continues in the third trimester of pregnancy and is suppressed by premature birth. J. Neurosci. 2013, 33, 411-423. [CrossRef] [PubMed]

63. Shchepetkina, A.A.; Hock, B.D.; Miller, A.; Kennedy, M.A.; Gieseg, S.P. Effect of 7,8-dihydroneopterin mediated CD36 down regulation and oxidant scavenging on oxidised low-density lipoprotein induced cell death in human macrophages. Int. J. Biochem. Cell Biol. 2017, 87, 27-33. [CrossRef]

64. Levine, J.D.; Khasar, S.G.; Green, P.G. Neurogenic inflammation and arthritis. Ann. N. Y. Acad. Sci. 2006, 1069, 155-167. [CrossRef] [PubMed]

65. Gosain, A.; Jones, S.B.; Shankar, R.; Gamelli, R.L.; DiPietro, L.A. Norepinephrine modulates the inflammatory and proliferative phases of wound healing. J. Trauma 2006, 60, 736-744. [CrossRef]

66. Grailer, J.; Haggadone, M.; Ward, P. Catecholamines promote an M2 macrophage activation phenotype (P1299). J. Immunol. 2013, 190, 63-67.

67. Grailer, J.J.; Haggadone, M.D.; Sarma, J.V.; Zetoune, F.S.; Ward, P.A. Induction of M2 regulatory macrophages through the beta2-adrenergic receptor with protection during endotoxemia and acute lung injury. J. Innate Immun. 2014, 6, 607-618. [CrossRef]

68. Qin, J.F.; Jin, F.J.; Li, N.; Guan, H.T.; Lan, L.; Ni, H.; Wang, Y. Adrenergic receptor beta2 activation by stress promotes breast cancer progression through macrophages M2 polarization in tumor microenvironment. BMB Rep. 2015, 48, 295-300. [CrossRef]

69. Pertovaara, A. Noradrenergic pain modulation. Prog. Neurobiol. 2006, 80, 53-83. [CrossRef]

70. Habler, H.J.; Janig, W.; Koltzenburg, M. Activation of unmyelinated afferents in chronically lesioned nerves by adrenaline and excitation of sympathetic efferents in the cat. Neurosci. Lett. 1987, 82, 35-40. [CrossRef]

71. Medina, M.G.; Lebovic, D.I. Endometriosis-associated nerve fibers and pain. Acta Obstet. Gynecol. Scand. 2009, 88, 968-975. [CrossRef] [PubMed]

72. Nichol, C.A.; Smith, G.K.; Duch, D.S. Biosynthesis and Metabolism of Tetrahydrobiopterin and Molybdopterin. Annu. Rev. Biochem. 1985, 54, 729-764. [CrossRef]

73. Latremoliere, A.; Costigan, M. GCH1, BH4 and pain. Curr. Pharm. Biotechnol. 2011, 12, 1728-1741. [CrossRef] [PubMed]

74. Rocha, M.G.; e Silva, J.C.; Ribeiro da Silva, A.; Candido Dos Reis, F.J.; Nogueira, A.A.; Poli-Neto, O.B. TRPV1 expression on peritoneal endometriosis foci is associated with chronic pelvic pain. Reprod. Sci. 2011, 18, 511-515. [CrossRef] [PubMed] 